\title{
G-Protein Level Quantification in Platelets and Leukocytes from Patients with Panic Disorder
}

\author{
Murray B. Stein, M.D., Guang Chen, M.D., William Z. Potter, M.D., \\ and Husseini K. Manji, M.D.
}

The objective of our study was to investigate if there are abnormalities in signal transducing $G$ proteins in patients with panic disorder. We utilized selective antibodies to quantitate the levels of the $G$ protein $\alpha$ subunits that regulate adenylyl cyclase activity $\left(\mathrm{G} \alpha_{\mathrm{S}}\right.$ and $\left.\mathrm{G} \alpha_{i 2}\right)$ and phosphoinositide turnover $\left(G \alpha_{q / 11}\right)$ in platelet membranes (and leukocyte membranes for $G \alpha_{s}$ ), and also carried out pertussis toxin $(P T)$ catalyzed $\left.{ }^{32} P\right] A D P$-ribosylation in platelet membranes from a group of 13 untreated panic disorder patients, 10 untreated social phobia patients, and 12 healthy subjects. There were no significant differences

KEY WORDS: G protein; Panic disorder; Adrenergic receptors; Social phobia

Patients with panic disorder (PD) experience symptoms such as racing heart, palpitations, and tremor which are strongly reminiscent of $\beta$-adrenergic receptor stimulation. This observation has led some researchers to suspect that panic attacks may be caused by elevated cate-

From the Anxiety \& Traumatic Stress Disorders Research Program, Department of Psychiatry, University of California, San Diego (MBS); the Section on Clinical Pharmacology, Experimental Therapeutics Branch, National Institute of Mental Health, Bethesda, Maryland (WZP); and the Molecular Pathophysiology Program, Departments of Psychiatry \& Pharmacology, Wayne State University School of Medicine, Detroit, MI.

Address correspondence to: Murray B. Stein, M.D., Anxiety \& Traumatic Stress Disorders Research Program, Department of Psychiatry (0603), University of California, San Diego, 9500 Gilman Drive, La Jolla, CA 92093-0603.

Received June 12, 1995; revised August 25, 1995; accepted September 21, 1995 among the three groups in the immunolabeling of $G \alpha_{S}$ in platelets or leukocytes, or in the immunolabeling of $\mathrm{G} \alpha_{i 1 / 2}$, $G \alpha_{q / 11}$, or PT-catalyzed [32P]ADP-ribosylation in platelets. Within the constraints imposed by using peripheral blood cells to reflect brain composition, our results do not provide support for $G$ protein abnormalities in patients with panic disorder. These results contrast with those obtained using identical methodology in bipolar affective disorder, where elevated $G \alpha_{s}$ in leukocytes has been reported (Manji et al. 1995). [Neuropsychopharmacology 15:180-186, 1996]

cholamine levels or other alterations in adrenergic receptor systems. Although the former hypothesis has garnered little empirical support (for review, see Stein and Uhde 1995), the latter hypothesis continues to be the subject of considerable scientific scrutiny.

Patients with PD have exaggerated behavioral responses to parenteral administration of the $\beta$-adrenergic agonist, isoproterenol, lending some support to the notion of $\beta$-adrenergic supersensitivity in this disorder (Nesse et al. 1984; Pohl et al. 1988). Direct examination of $\beta$-adrenergic receptors on peripheral blood elements from patients with PD has yielded conflicting results. Three studies have found reduced $\beta$-adrenoceptor density on leukocytes from patients with PD compared to healthy controls (Brown et al. 1988; Aronson et al. 1989; Madock et al. 1993), one study found an increase (Albus et al. 1986), and our own study using the highly $\beta$-adrenoselective ligand ${ }^{125} \mathrm{I}-$ pindolol found no difference ( $\mathrm{Hu}-$ zel et al. 1993).

In contrast to the conflicting data with regard to 
$\beta$-adrenoceptors, per se, results from several studies suggest a possible alteration distal to the receptor in patients with PD. Lymphocytes (Maddock et al. 1993) and platelets (Charney et al. 1989) stimulated from patients with PD exhibit abnormal levels of $\beta$ - or $\alpha_{a}$-adrenoceptor inhibition of cyclic AMP (cAMP) generation, respectively. These findings could be explained by dysfunction at the level of guanine nucleotide binding proteins ( $G$ proteins), cellular transducing proteins that couple receptors to various effectors (Manji 1992).

Guanine nucleotide binding proteins ( $G$ proteins) are a ubiquitous family of proteins that serve the critical role of transducers of information across the plasma membrane, coupling receptors to various effectors (Gilman 1987; Spiegel et al. 1992; Taylor 1990). The G proteins are heterotrimers localized to the inner surface of the plasma membrane and consist of an $\alpha$ subunit that binds (and hydrolyzes) GTP, and $\beta$ and $\gamma$ subunits that form a tightly but noncovalently linked dimer (Gilman 1987; Spiegel et al. 1992; Taylor 1990). Because information traverses catalytically across a $G$ protein coupled system in a GTPase cycle, there is a several thousandfold amplification of the original signal. Although G proteins are present in all eukaryotic cells and control various metabolic, humoral and developmental functions, they are especially important in the central nervous system (CNS), where they serve the critical roles of first amplifying and "weighting" extracellularly generated neuronal signals and then transmitting these integrated signals to effectors, thereby forming the basis for a complex information processing network (Ross 1989; Manji 1992; Manji et al. 1995a). The high degree of complexity generated by the interactions of $G$ proteincoupled receptors may be one mechanism by which neurons acquire the flexibility for generating the wide range of responses observed in the nervous system (Freissmuth et al. 1989; Ross 1989). This has led to the proposal that $G$ proteins may be involved in pathways regulating such diverse vegetative functions as mood, appetite, and wakefulness (Manji 1992). Given the variety of functions subserved by $\mathrm{G}$ protein-coupled signal transduction, it is not surprising that abnormalities in $\mathrm{G}$ protein-coupled pathways have been implicated in a variety of human diseases and pathophysiologic states (for reviews, see Manji 1992; Milligan and Wakelman 1992; Spiegel et al. 1993)

At present, there is some evidence for the involvement of $G$ proteins in the etiology and/or pathophysiology of certain neuropsychiatric disorders. Studies from three independent laboratories have recently demonstrated alterations in the levels and/or activation of the $\alpha$ subunit of the stimulatory $G$ protein $(\alpha s)$ in peripheral cells from subjects with bipolar affective disorder (Schreiber et al. 1992; Young et al. 1994; Manji et al. 1995b). Interestingly, the study by Young and associates (1994) found elevated levels of $\alpha$ s in depressed bipolar patients, whereas that by Manji et al. (1995b) found the same abnormality studying either manic or lithiumtreated euthymic subjects, suggesting that this biochemical abnormality may be state independent.

An increasing body of evidence also suggests that antidepressants, upon chronic administration, may exert effects at post-receptor sites, in particular at the level of $\mathrm{G}$ proteins. Thus, following chronic treatment, desipramine causes a functional uncoupling of the $\beta$ receptor from Gs in rat cortex (Okada et al. 1986) and interferes with the breakdown of the $\beta$ adrenergic receptor high-affinity ternary complex (Yamaoka et al. 1988). In addition, the chronic administration of tricyclic antidepressants and the monoamine oxidase inhibitor, clorgyline, have recently been demonstrated to regulate the protein and mRNA levels of Gas (Lesch and Manji 1992), suggesting a coordinate downregulation of the $\beta$-adrenoceptor-Gs-adenylyl cyclase complex by antidepressants (Sugrue 1983; Sulser et al. 1984).

In view of the clinical overlap between affective disorders and anxiety disorders (Stein and Uhde 1990), as well as the well established efficacy of tricyclic antidepressants and monoamine oxidase inhibitors in the treatment of PD (Taylor 1995), it is of interest to examine the signal transducing $G$ proteins in panic disorder. Thus, in the present study, we have sought to directly examine the levels of $G$ protein $\alpha$ subunits in both platelets and leukocytes from a group of untreated PD patients, an anxious comparison groups (untreated social phobia patients), and a healthy comparison group. Using specific antibodies, we quantitate the levels of the $G$ protein subunits mediating stimulation and inhibition

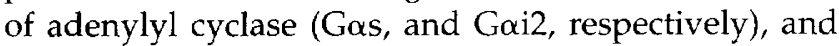
stimulation of phosphoinositide turnover (Goq/11). Additionally, we have examined pertussis- and choleratoxin catalyzed [ ${ }^{32} \mathrm{P}$ ]ADP-ribosylation in platelets from these patients. To the best of our knowledge, this is the first study to directly examine G protein levels in patients with panic (or any other anxiety) disorder.

\section{METHODS}

\section{Patients}

The group of untreated, PD patients consisted of $10 \mathrm{fe}-$ male and three male subjects, average age $37 \pm 11$ years. The comparison group of untreated social phobia patients consisted of four female and six male subjects, average age $31 \pm 10$ years. Patients were diagnosed by semistructured interview (a version of the Structured Clinical Interview [SCID-P; Spitzer et al. 1990] modified for DSM-IV). Patients were recruited from among those attending the Anxiety Disorders Clinic at St. Boniface Hospital in Winnipeg, Manitoba. Patients had not received any psychotropic medications for at least 2 weeks 
prior to study. All subjects were determined to be free of significant medical illness by medical history, a complete physical examination, complete blood count and differential, serum electrolytes, hepatic and renal function tests, thyroid function tests, and urinalysis.

The healthy comparison group consisted of nine women and three men (average age $39 \pm 11$ years) from the community, recruited by posted advertisements and word of mouth. These subjects were free of all medications for at least 2 weeks prior to entry into the study, had no active medical problems, and had no personal or family history of Axis I psychiatric disorders, alcoholism, or drug abuse as determined by clinical interview with the subject.

\section{Blood Cell Isolation and Membrane Preparation}

Blood samples $(50 \mathrm{ml})$ were obtained by venipuncture. Mononuclear leukocytes (MNLs) and platelets were isolated from the fresh blood (with sodium heparin as the anticoagulant) using a Histo-Paque gradient, with minor modification of the procedure of Boyum (1968). The buffy coat remaining after the removal of the platelet rich plasma (PRP) was removed with a Pasteur pipette, diluted 1:1 with phosphate-buffered saline (PBS) and carefully layered onto Histo-Paque (Sigma Chemicals, St. Louis, USA) and subjected to gradient centrifugation. The leukocyte band was carefully removed, washed with PBS, centrifuged, and the pellet frozen at $-80^{\circ} \mathrm{C}$ until used. Ten millimeters of blood routinely yielded $1-2 \times 10^{6}$ mononuclear cells consisting of over $90 \%$ clear mononuclear leukocytes. Cells were homogenized, washed in ice cold isotonic buffer containing 2 $\mathrm{mmol} / \mathrm{L}$ EDTA, $5 \mathrm{mmol} / \mathrm{L}$ EGTA, $1 \mathrm{mmol} / \mathrm{L}$ dithiothreitol, $1 \mathrm{mg} / \mathrm{ml}$ leupeptin, $2 \mathrm{mmol} / \mathrm{L}$ phenylmethysulfonyl fluoride, $100 \mathrm{mmol} / \mathrm{L}$ benzamidine, $\mathrm{pH} 7.5$. The suspension was sonicated with $4 \times 10$ second pulses, and intact cells removed by centrifugation at $1500 \times g$. The leukocyte lysate was then centrifuged in an ultracentrifuge at $45,000 \times g$ for 1 hour at $4^{\circ} \mathrm{C}$ to obtain a crude plasma membrane fraction. After resuspension in $10 \mathrm{mmol} / \mathrm{L}$ Tris- $\mathrm{HCl}$, $\mathrm{pH} 7.5$, membrane protein concentrations were determined in triplicate according to the method of Bradford (1968), and the samples were frozen at $-80^{\circ} \mathrm{C}$ until use.

After removal of the PRP, the platelet pellet was obtained by centrifugation of the PRP at $1200 \mathrm{~g}$ for $15 \mathrm{~min}$ utes, and the pellet rinsed with PBS and then frozen at $-80^{\circ} \mathrm{C}$ until subsequent use. Pellets were resuspended in ice-cold Tris buffer, containing $2 \mathrm{mmol} / \mathrm{L}$ EDTA, $5 \mathrm{mmol} / \mathrm{L}$ EGTA, $1 \mathrm{mmol} / \mathrm{L}$ dithiothreitol, $1 \mathrm{mg} / \mathrm{ml}$ leupeptin, $2 \mathrm{mmol} / \mathrm{L}$ phenylmethysulfonyl fluoride, 100 mmol/L benzamidine, pH 7.5. The suspension was sonicated with $4 \times 10$ second pulses, and intact platelets removed by centrifugation at $1500 \times g$. The platelet lysate was then centrifuged in an ultracentrifuge at $45,000 \mathrm{~g}$ for 1 hour at $4^{\circ} \mathrm{C}$ to obtain a crude plasma membrane fraction. Following resuspension in $10 \mathrm{mmol} / \mathrm{L}$ Tris$\mathrm{HCl}, \mathrm{pH} 7.5$, the membrane protein concentrations were determined in triplicate as above, and the samples were then frozen in appropriate aliquots at $-80^{\circ} \mathrm{C}$ until use.

\section{Immunoblot Analysis}

The linearity of the plasma membrane protein concentration for Western blotting was ascertained by resolution of selected concentrations of protein (between 10 and $200 \mu \mathrm{g})$. Subsequent studies were performed using a protein concentration known to be within the linear range for immunolabeling of the $G$ protein $\alpha$ subtypes. Western blotting was performed on all samples in duplicate using previously described procedures with selective antibodies directed against synthetic decapeptides corresponding to the carboxy termini of the respective $G \alpha_{\mathrm{S}}, \mathrm{G} \alpha_{\mathrm{q} / 11}$ and $\mathrm{G} \alpha_{\mathrm{i} 1 / 2}$ subunits (all from Dupont, USA). In brief, 25 to $50 \mu \mathrm{g}$ of membrane protein were solubilized in denaturing buffer (Laemmli 1970 ), and proteins were resolved by SDS-PAGE on $10 \%$ polyacrylamide gels. Proteins thus resolved were electrophoretically transferred onto nitrocellulose paper. Protein binding sites on the nitrocellulose were blocked with low detergent "Blotto" containing 5\% nonfat dry milk. After thorough washing with distilled water, the blots were incubated at room temperature overnight with specific polyclonal anti-G $\alpha_{S}(\mathrm{RM})$, anti-G $\alpha_{\mathrm{i}-2}(\mathrm{AS})$, antiG $\alpha_{\mathfrak{q} / 11}$ (QL) antiserum (all 1:5000 dilution), and after appropriate washing, were incubated with $\left[{ }^{125}\right]$ protein A (Amersham, Arlington Heights, IL) for 2 hours at room temperature. The labeled blots were then washed, dried, and exposed to $x$-ray film with intensifying screens at $-80^{\circ} \mathrm{C}$. Quantitation of the immunoblots was performed by densitometric scanning of the autoradiograms using an Image Analysis system (NIH Image 1.32). An aliquot of pooled "standard" platelet or MNL membranes was run on one lane of every gel, and the immunolabeling was calculated relative to this standard. Data were normalized against pooled platelet or leukocyte membrane fractions, which were run on all blots to minimize between blot variability.

\section{Pertussis Toxin Catalyzed [32P]ADP-Ribosylation}

Pertussis-toxin catalyzed [ $\left.{ }^{32} \mathrm{P}\right] \mathrm{ADP}-$ ribosylation of platelet Gi was performed using previously described methods (Hsiao et al. 1992; Odagki et al. 1992). In brief, the frozen membranes were thawed and resuspended in potassium phosphate buffer ( $\mathrm{pH} 7.5,1.5 \mathrm{mg}$ protein/ $\mathrm{ml}$ ), then incubated at $37^{\circ} \mathrm{C}$ for 60 minutes in a final volume of $0.2 \mathrm{ml}$, containing $100 \mathrm{mmol} / \mathrm{L}$ potassium phosphate buffer ( $\mathrm{pH} 7.5)$, phosphate buffer $(\mathrm{pH} 7.5,1.5 \mathrm{mg}$ protein $/ \mathrm{ml}$ ), then incubated at $37^{\circ} \mathrm{C}$ for 60 minutes in a final volume of $0.2 \mathrm{ml}$, containing $100 \mathrm{mmol} / \mathrm{L}$ potassium phosphate buffer ( $\mathrm{pH} 7.5), 100 \mathrm{mmol} / \mathrm{L}$ thymi- 


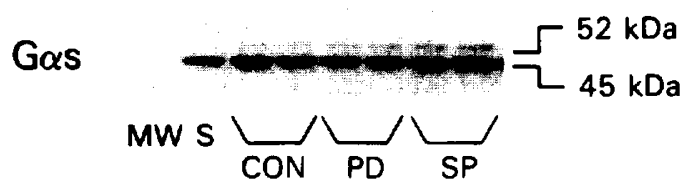

(A)
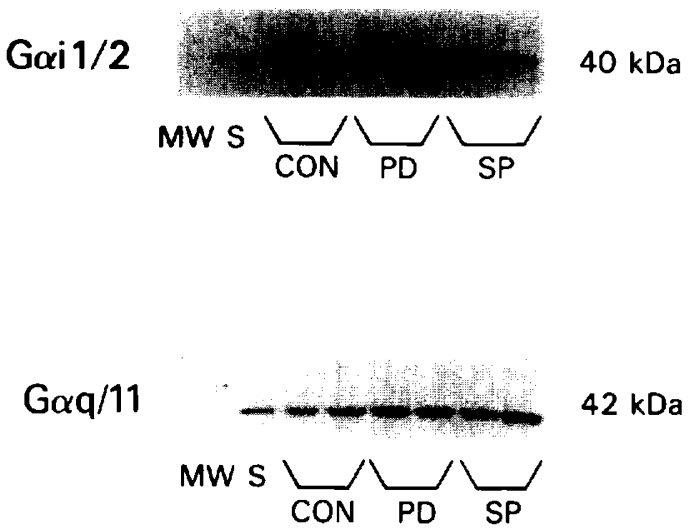

Figure 1. Representative Western blots of G protein $\alpha$ subunits. Platelet membranes were prepared according to the methods described in the text and subjected to SDS-PAGE on $10 \%$ polyacrylamide gels. Proteins thus resolved were electrophoretically transferred onto nitrocellulose paper. Following the blocking of protein binding sites on the nitrocellulose membranes, the blots were incubated at room temperature overnight with specific polyclonal anti-G $\alpha_{\mathrm{s}}$ (RM) (A), anti$\mathrm{G} \alpha_{\mathrm{il}-2}$ (AS) (B), anti-G $\alpha_{\mathrm{q} / 11}$ (QL) (C) antiserum (all 1:5000 dilution), and after appropriate washing, were incubated with $\left[{ }^{125}\right.$ I] protein $\mathrm{A}$ for 2 hours at room temperature. The labeled blots were then washed, dried, and exposed to x-ray film with intensifying screens at $-80^{\circ} \mathrm{C}$. Estimation of the molecular weights of labeled protein bands was made by comparison with molecular weight standards. An aliquot of pooled "standard" platelet or MNL membranes were run on one lane of every gel to reduce inter-blot variability, and the quantitation of the appropriate band was calculated relative to this standard. Abbreviations: $\mathbf{M W}=$ molecular weight standards; $\mathbf{S}=$ standard platelet membranes; $\mathbf{C O N}=$ healthy control subjects; $\mathbf{P D}=$ panic disorder patients; $\mathbf{S P}=$ social phobia patients.

dine, $10 \mathrm{mmol} / \mathrm{L}$ arginine, $0.5 \mathrm{mmol} / \mathrm{L}$ ATP, $50 \mu \mathrm{mol} / \mathrm{L}$ GTP, $10 \mu \mathrm{mol} / \mathrm{L}\left[\alpha^{-32} \mathrm{P}\right]-\mathrm{NAD}(25 \mathrm{Ci} / \mathrm{mMol}$, New England Nuclear, Boston MA) with and without activated toxin. Prior to incubation, pertussis toxin ( $5 \mu \mathrm{g} /$ tube) (List Biological laboratories, Campbell, CA) was activated with $10 \mathrm{mmol} / \mathrm{L}$ dithiothreitol for 30 minutes at $37^{\circ} \mathrm{C}$. The linearity of the plasma membrane protein concentration for pertussis toxin catalyzed [32 P] labeling was ascertained by resolution of selected concentrations of membrane protein (between 20 and $400 \mu \mathrm{g}$ ). Subsequent studies were performed using a protein concentration known to be within the linear range for toxin catalyzed [32P] labeling. Pertussis toxin catalyzed [22P]ADP-ribosylation of all samples was performed in duplicate.

Labeled membranes were washed in ice cold buffer; proteins were solubilized and subjected to SDS-PAGE on $10 \%$ polyacrylamide gels using the method of Laem$\mathrm{mli}$ (1970). The gels were dried and exposed to an X-ray film (Kodak X-omat, Rochester, NY) with an intensifying screen at $-80^{\circ} \mathrm{C}$. Estimation of the molecular weights of labeled protein bands was made by comparison with molecular weight standards. An aliquot of pooled "standard" platelet or MNL membranes was run on one lane of every gel, and the quantitation of $\left[{ }^{32} \mathrm{P}\right]$ incorporation was calculated relative to this standard.

\section{Statistical Analysis}

Analysis of variance (ANOVA) was used to compare means among the three groups. Variances are reported as \pm SD. Statistical significance is determined by $p<.05$ using a two-tailed test.

\section{RESULTS}

Figure $1(A-C)$ shows representative immunoblots of $G$ protein $\alpha$ subunit immunoreactivity in platelet membranes from healthy control subjects (CON), PD patients, and social phobia patients (SP). All three polyclonal $G$ protein antisera used in the present study selectively recognized distinct $G$ protein $\alpha$ subunits as has been previously described (Mumby et al. 1986; Simonds et al. 1993). Thus, the $G \alpha_{S}$ antisera (A) recognized a major band migrating with an apparent molecular mass of $45 \mathrm{kDa}$, and a minor band migrating at 52 $\mathrm{kDa}$ in both leukocyte and platelet membranes. The $\mathrm{G} \alpha_{\mathrm{i} 1 / 2}$ antisera (B) recognized a single band (known to be predominantly $\alpha_{\mathrm{i} 2}$ in human platelets) with apparent molecular mass of $40 \mathrm{kDa}$, and the $\mathrm{G} \alpha_{\mathrm{q}} / 11$ antisera (C) recognized a single band with apparent molecular mass of $42 \mathrm{kDa}$ in both leukocyte and platelet membranes. Quantitation of the immunoblots was performed by densitometric scanning of the autoradiograms, and the data were normalized against pooled platelet or leukocyte membranes, which were run on all blots to minimize between blot variability.

\section{Leukocyte and Platelet $\mathrm{G} \alpha_{\mathrm{s}}$}

Figure 2 shows the results of leukocyte and platelet membrane immunolabeling of the major $(45 \mathrm{kDa})$ form of $G \alpha_{\mathrm{S}}$ in the three groups. There were no significant between-groups differences (ANOVA, $p=\mathrm{NS}$ ). The three groups also did not differ significantly in immunolabeling of the $52 \mathrm{kDa}$ form of $\mathrm{G} \alpha_{\mathrm{s}}$ (data not shown). 


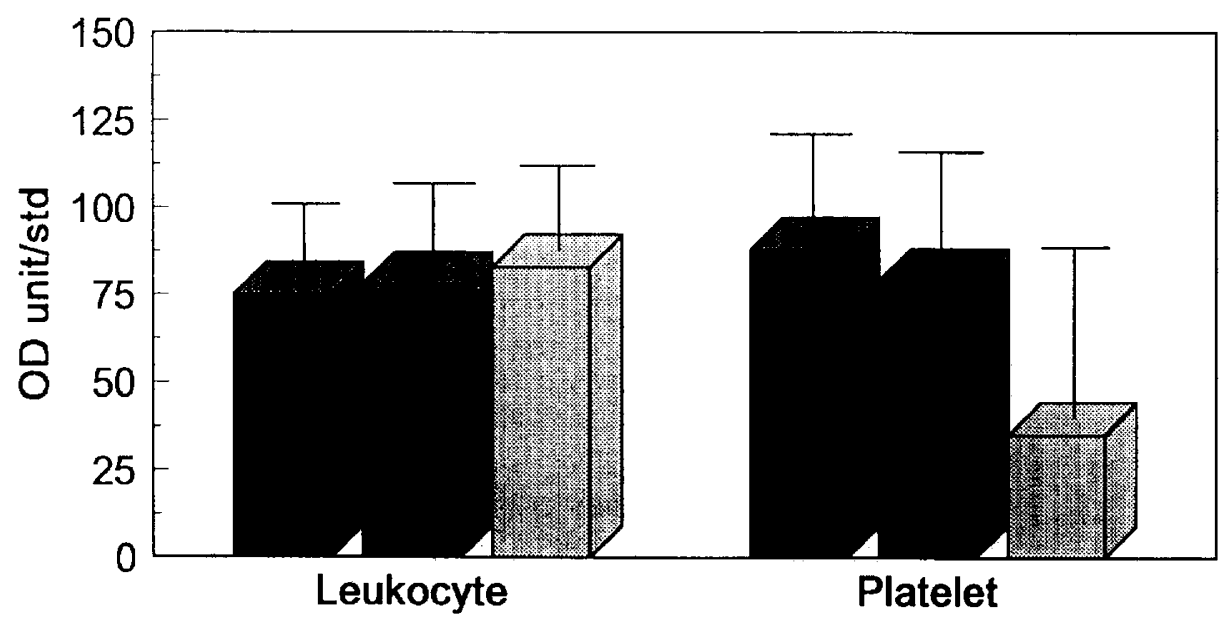

Figure 2. Leukocyte and platelet membrane immunolabeling of the major (45 $\mathrm{kDa})$ form of $\mathrm{G} \alpha_{s}$ in patients with panic disorder (dark/left-hand bars), healthy control subjects (middle bars), and patients with social phobia (light/right-hand bars). Data refer to the $45 \mathrm{kDa}$ band and are normalized to a pooled standard run with each gel. All between groups comparisons are nonsignificant.

\section{Platelet $\mathrm{G} \alpha_{\mathrm{i} 1 / 2}$ and Pertussis Toxin Catalyzed [32 $\left.\mathrm{P}\right]$ ADP-Ribosylation}

In platelets there were no statistically significant differences in the immunolabeling of $\mathrm{G}_{\mathrm{i} 1 / 2}$ in the three groups $(\mathrm{PD}=75 \pm 18 ; \mathrm{SP}=101 \pm 43 ; \mathrm{CON}=99 \pm 57$ OD units/std; $p=$ NS).

Pertussis toxin catalyzed the [ $\left.{ }^{32} \mathrm{P}\right] \mathrm{ADP}$-ribosylation of a single major band with an apparent molecular mass of $40 \mathrm{kDa}$. As was the case for immunolabeling of $\mathrm{G} \alpha_{\mathrm{i} 1 / 2}$ in platelet membranes, there were no statistically significant differences in the levels of pertussis toxin catalyzed [ ${ }^{32} \mathrm{P}$ ]labeling of $\mathrm{G} \alpha_{\mathrm{i} 1 / 2}$ in platelet membranes from the three groups: $(\mathrm{PD}=108 \pm 41$; $\mathrm{SP}=64 \pm 31$; $\mathrm{CON}=103 \pm 68$ OD units $/$ std; $p=\mathrm{NS}$ ).

\section{Platelet $\mathrm{G} \alpha_{\mathrm{q} / 11}$}

There were no significant differences in the immunolabeling of $\mathrm{G} \alpha_{\mathrm{q}} / 11$ in platelet membranes from the three groups $(\mathrm{PD}=82 \pm 39 ; \mathrm{SP}=100 \pm 129 ; \mathrm{CON}=61 \pm 48$ $\mathrm{OD}$ units/std; $\mathrm{F}[2,34]=0.71 ; p=\mathrm{NS}$ ).

\section{CONCLUSIONS}

This study is the first that we are aware of to directly quantitate the levels of the major $G$ protein $\alpha$ subunits in peripheral blood elements from patients with anxiety disorders. We did not observe significant differences in the levels of $\mathrm{G} \alpha_{\mathrm{s}}, \mathrm{G} \alpha_{11 / 2}, \mathrm{G} \alpha_{\mathrm{q} / 11}$ or in the pertussis toxin catalyzed [ $\left.{ }^{32} \mathrm{P}\right] \mathrm{ADP}-$ ribosylation in tissues from subjects in the three groups (i.e., panic disorder, social phobia, and healthy comparison subjects).

The relevance of our findings for the pathophysiology of panic disorder seems reasonably clear, despite one major caveat-extrapolating from the findings obtained in peripheral blood cells to signal transduction systems in the central nervous system. The major limitation of these peripheral models is that the blood cells are exposed to a potentially completely different environment (including circulating catecholamines and hormones) (Maisel et al. 1990; Van Tits et al. 1990) to that of brain tissue, which may lead to marked differences in $G$ protein-coupled signal transduction pathways (Milligan and Green 1991; Hadcock and Malbon 1993). Keeping this limitation in mind, though, our results do not support an abnormality in $\mathrm{G}$ protein levels in panic disorder.

These findings are of additional interest in light of the fact that elevations in leukocyte and platelet $\mathrm{G} \alpha_{\mathrm{s}}$ immunolabeling have been found by our group, using identical methods, in patients with bipolar affective disorder (Manji et al. 1995b). Similarly, Young et al. (1994) found elevated levels of $G \alpha$ s in bipolar depressed-but not unipolar depressed-subjects. Elevated levels of Gos have also been found in men at high risk for alcoholism on the basis of a positive family history (Wand et al. 1994). Taken together with our findings, these observations suggest that alterations in Gas are associated with some mental disorders (e.g., bipolar disorder, alcoholism), but not others (e.g., panic disorder, social phobia, unipolar depression). A challenge for researchers in this field will be to apply this information to elucidate the mechanism(s) by which a shared abnormality in G protein expression might be implicated in the pathophysiology of those disorders in which the abnormality occurs.

\section{ACKNOWLEDGMENTS}

The authors are grateful to Mariette Chartier, Geri Anderson, and Barbara Torchia for their assistance. This study was supported in part by a grant to MBS from the Medical Research Council of Canada. 


\section{REFERENCES}

Albus M, Bondy B, Ackenheil M (1986): Adrenergic receptors on blood cells: Relation to the pathophysiology of anxiety. Clin Neuropharmacol 9 (suppl): 359-361

Aronson TA, Carasiti I, McBane D, Whitaker-Azmitia P (1989): Biological correlates of lactate sensitivity in panic disorder. Biol Psychiatry 26:463-477

Bourne, HR, Nicoll R (1993): Molecular machines integrate coincident synaptic signals. Cell 72:65-75

Boyum A (1968): Isolation of mononuclear cells and granulocytes from blood. II. Isolation of mononuclear cells by one centrifugation and sedimentation at $1 \mathrm{~g}$. Scand J Clin Lab Invest 21:77-89

Bradford MM (1968): A rapid and sensitive method for the quantitation of microgram quantities of protein utilizing the principle of protein-dye binding. Anal. Biochem $72: 248-254$

Brown SL, Charney DS, Woods SW, Heninger GR, Tallman J (1988): Lymphocyte beta-adrenergic receptor binding in panic disorder. Psychopharmacology 94:24-28

Charney DS, Innis RB, Duman RS, Woods SW, Heninger GR (1989): Platelet alpha-2-receptor binding and adenylate cyclase activity in panic disorder. Psychopharmacology 98:102-107

Freissmuth M, Casey PJ, Gilman AG (1989): G proteins control diverse pathways of transmembrane signaling. Faseb ] 3:2125-2131

Gilman AG (1989): G proteins: Transducers of receptor-generated signals. Annu Rev Biochem 56:615-649

Hadcock JR, Malbon CC (1993): Agonist regulation of gene expression of adrenergic receptors and $G$ proteins. J Neurochem 60:1-9

Hsiao JK, Manji HK, Chen GA, Bitran JA, Risby ED, Potter WZ (1992): Lithium administration modulates platelet $\mathrm{Gi}$ in humans. Life Sci 50:227-233

Huzel LL, Delaney SM, Stein MB (1993): Lymphocyte $\beta$-adrenergic receptors in panic disorder: Findings with a highly selective ligand and relationship to clinical parameters. J Anxiety Disorders 7:349-357

Laemmli UK (1970): Cleavage of structural proteins during the assembly of the head of the bacteriophage. Nature 227:680-685

Lesch KP, Manji HK (1992): Signal-transducing G proteins and antidepressant drugs: Evidence for modulation of alpha subunit gene expression in rat brain. Biol Psychiatry 32:549-579

Maddock RJ, Carter CS, Magliozzi JR, Gietzen DW (1993): Evidence that decreased function of lymphocyte beta adrenoreceptors reflects regulatory and adaptive processes in panic disorder with agoraphobia. Am J Psychiatry 150:1219-1225

Maisel AS, Knowlton KU, Fowler P, Rearden A, Ziegler MG, Motulsky HJ, Insel PA, Michel MC (1990): Adrenergic control of circulating lymphocyte subpopulations. Effects of congestive heart failure, dynamic exercise, and terbutaline treatment. J Clin Invest 85:462-467

Manji HK (1992): G proteins: Implications for psychiatry. Am J Psychiatry 149:746-760
Manji HK, Potter WZ, Lenox RH (1995a): Signal transduction pathways: Molecular targets for lithium's actions. Arch Gen Psychiatry 52:531-543

Manji HK, Chen G, Shimon H, Hsiao JK, Potter WZ, Belmaker RH (1995b): Guanine nucleotide-binding proteins in bipolar affective disorder: Effects of long-term lithium treatment. Arch Gen Psychiatry 52:135-144

Milligan G, Wakelman M (1992): G Proteins: Signal Transduction and Disease. New York, Academic Press

Milligan G, Green A (1991): Agonist control of G-protein levels. Trends Pharmacol Sci 12:207-209

Mitchell FM, Mullaney I, Godfrey PP, Arkinstall SJ, Wakelam MJ, Milligan G (1991): Widespread distribution of Gq alpha/G11 alpha detected immunologically by an antipeptide antiserum directed against the predicted C-terminal decapeptide. Febs Lett 287:171-174

Mumby SM, Kahn RA, Manning DR, Gilman AG (1986): Antisera of designed specificity for subunits of guanine nucleotide-binding regulatory proteins. Proc Natl Acad Sci USA 83:265-269

Nesse RM, Cameron OG, Curtis GC, McCann DS, HuberSmith, MJ (1984): Adrenergic function in patients with panic anxiety. Arch Gen Psychiatry 41:771-776

Odagki Y, Koyama T, Yamashita I (1992): Quantitative determination of pertussis-sensitive $G$ proteins using [32P]ADPribosylation in human platelet membranes: negative correlations with ages. Life Sci 50:1851-1857

Okada F, Tokumitsu Y, Ui M (1986): Desensitization of betaadrenergic receptor-coupled adenylate cyclase in cerebral cortex after in vivo treatment of rats with desipramine. J Neurochem 47:454-459

Pohl R, Yeragani VK, Balon R, Rainey JM, Lycaki H, Ortiz A, Berchou R, Weinberg P (1988): Isoproterenol-induced panic attacks. Biol Psychiatry 24:891-902

Ross EM (1989): Signal sorting and amplification through G protein-coupled receptors. Neuron 3:141-152

Schreiber G, Avissar S, Danon A, Belmaker RH (1991): Hyperfunctional $\mathrm{G}$ proteins in mononuclear leukocytes of patients with mania. Biol Psychiatry 29:273-280

Simonds WF, Goldsmith PK, Woodward CJ, Unson CG, Spiegel AM (1993): Receptor and effector interactions of Gs. Functional studies with antibodies generated to the alpha s carboxyl-terminal decapeptide. Febs Lett 249: 189-194

Spiegel AM, Shenker A, Weinstein LS (1992): Receptor-effector coupling by $G$ proteins: Implications for normal and abnormal signal transduction. Endocr Rev 13:536-565

Spiegel AM, Weinstein LS, Shenker A (1993): Abnormalities in $G$ protein-coupled signal transduction pathways in human disease. J Clin Invest 92:1119-1125

Spitzer RL, Williams JBW, Gibbon M, First MB (1990): Structured Clinical Interview for DSM-III-R-Patient Edition (SCID-P). Washington, DC, American Psychiatric Press

Stein, M.B., Uhde, T.W. (1995): The biology of anxiety disorders. In American Psychiatric Press Textbook of Psychopharmacology. Nemeroff CB, Schatzberg AF (eds), Washington, DC, American Psychiatric Press, pp 501-521

Stein MB, Uhde TW (1990): Panic disorder and major depression: Lifetime relationship and biological markers. In Ballenger JC (ed), Clinical Aspects of Panic Disorder. New York, Wiley-Liss Inc., pp 151-168 
Sugrue MF (1983): Do antidepressants possess a common mechanism of action? Biochem Pharmacol 32:1811-1817

Sulser F, Gillespie DD, Mishra R, Manier DH (1984): Desensitization by antidepressants of central norepinephrine receptor systems coupled to adenylate cyclase. Ann NY Acad Sci 430:91-101

Taylor CB (1995): Treatment of anxiety disorders. In Nemeroff CB, Schatzberg AF(eds), American Psychiatric Press Textbook of Psychopharmacology. Washington, DC, American Psychiatric Press, pp 641-656

Taylor CW (1990): The role of G proteins in transmembrane signaling. Biochem J 272:1-13

Van Tits LJ, Michel MC, Grosse WH, Happel M, Eigler FW, Soliman A, Brodde OE (1990): Catecholamines increase lymphocyte beta 2-adrenergic receptors via a beta 2-adrenergic, spleen-dependent process. Am J Physiol 258:E191-E202
Wand GS, Waltman C, Martin CS, McCaul ME, Levine MA, Wolfgang D (1994): Differential expression of guanosine triphosphate binding proteins in men at high and low risk for the future development of alcoholism. J Clin Invest 94:1004-1011

Werstiuk ES, Steiner M, Burns T (1990): Studies on leukocyte $\beta$-adrenergic receptors in depression: A critical appraisal. Life Sci 47:85-105

Yamaoka K, Nanba T, Nomura S (1988): Direct influence of antidepressants on GTP binding protein of adenylate cyclase in cell membranes of the cerebral cortex of rats. J Neural Transm 71:165-175

Young LT, Li PP, Kamble A, Siu KP, Warsh JJ (1994): Mononuclear leukocyte levels of $G$ proteins in depressed patients with bipolar disorder or major depressive disorder. Am J Psychiatry 151:594-596 